\title{
Review
}

\section{The farm animal genetic resources of Turkey: sheep - I - common and rare breeds}

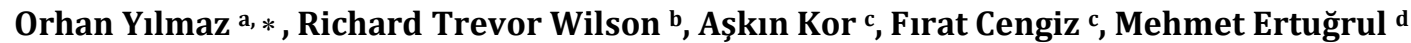 \\ a Iğdır University, Faculty of Agriculture, Department of Animal Science, 76000 Iğdır-Turkey \\ ${ }^{b}$ Bartridge Partners, Umberleigh, Devon EX37 9AS, United Kingdom \\ c Yüzüncü Yll University, Faculty of Agriculture, Department of Animal Science, 65080 Van-Turkey \\ ${ }^{d}$ Ankara University, Faculty of Agriculture, Department of Animal Science, 06110 Ankara-Turkey \\ *Corresponding author: zileliorhan@gmail.com
}

\begin{abstract}
Biodiversity richness indicates the economic and genetic wealth of a country. Turkey is like a bridge between Europe and Asia; hence it has been used by traders, travelers or intruders for centuries which cause existence of considerable different kinds of domestic animals. Although some of genotypes extinct or crucially under extinction risk, domestic livestock resources of Turkey have not been adequately appraised. On one hand new breeds are domesticated by human, on the other hand much more breeds are getting extinct by human. Creation new breeds supplies to human welfare, but extinction of native breeds also leads to exacerbate human life. In this study, domestic livestock biodiversity and conservation of Turkey is intended to explain by giving brief examples about 21 sheep breeds of Turkey.
\end{abstract}

Keywords: breed characteristic, conservation, livestock, native breed

\section{Introduction}

The sheep is the second domesticated animal after dog (Yılmaz 1995). Turkey has 21.8 million sheep and is one of the most important sheep producer in the world (Türkiye İstatistik Kurumu 2011). Turkish sheep breeds are divided into 2 groups as fat or thin tailed breeds (Table 1). Fat tailed sheep are in majority in Turkish sheep population. The reason is that sheep breeding is generally seemed as a second job after crop production by Turkish farmers. Sheeps are grazed in open land in spring season. In this season animals complete their body condition up to normal body size. At the end of June, generally grass becomes dry on pasture and in July cereals are harvested. After July, sheeps generally eat either dry grass on pasture or stubble leftover by cereals on fields until winter season, so then sheeps put on fat either under skin or around intestine and kidneys, but especially in tail.

Table 1. An overview to the common and rare sheep breeds of Turkey

\begin{tabular}{|c|c|c|}
\hline & Fat Tailed & Thin Tailed \\
\hline Common & $\begin{array}{l}\text { İvesi, Dağlıç, } \\
\text { Morkaraman, } \\
\text { Akkaraman }\end{array}$ & Karayaka, Kıvırcık, \\
\hline Rare & $\begin{array}{l}\text { Çandır, Çine Çaparı, } \\
\text { Hemşin, Herik, Kangal, } \\
\text { Karaman, Karacadağ, } \\
\text { Karagül, Karakaș, } \\
\text { Norduz, Güney Karaman, } \\
\text { Tuj }\end{array}$ & $\begin{array}{l}\text { İmroz (Gökçeada), } \\
\text { Karya, Pırlak, } \\
\text { Sakız, }\end{array}$ \\
\hline
\end{tabular}

Tail grows up to maximum size before winter season. During winter season sheep are fed by lots of wheat straw and some wheat bran. Sheep can only survive by consuming fat in tail by the end of the winter season. Due to inadequate feeding in winter sheep lose some part of body tissues besides fat. After winter season sheep can first complete these body tissues and then after July they put on fat again. This circle repeats every year; hence fat tail is very crucial for sheeps (Sönmez 1978).

\subsection{Common Breeds}

The common sheep breeds of Turkey are İvesi, Dağlıç, Karayaka, Kıvırcık, Morkaraman, and Akkaraman (Table 2). The breeds of Karayaka and Kıvırcık have thin tail and rest have fat tail.

1.1.1. İvesi (Figure 1) also known as Awassi which mainly lives in southeast Turkey (Mason 1996) and endangered (Ertuğrul et al. 2009). İvesi sheeps are featured with mid-sized white body, having black or brown spots on head, neck and legs. Both male and female are polled (TAGEM 2009).

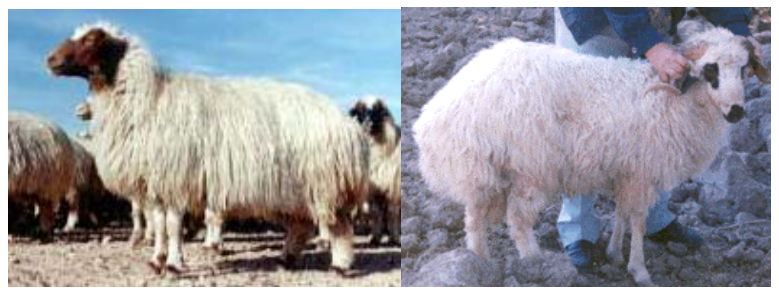

Figure 1. İvesi Sheep

Figure 2. Dağlıç Sheep

1.1.2. Dağlıç (Figure 2) lives in western Anatolia. It is a coarse wool, meat and milk type breed with black spots on head and legs. Male is usually horned female is usually polled (Mason 1996). Dağlıç is nearly extinct and 200 sheep have been under protection by three farmers in Bolvadin (Ertuğrul et al. 2009). 
Table 2. Fat and thin tailed common native sheep breeds of Turkey

\begin{tabular}{|c|c|c|c|c|c|c|}
\hline \multirow{2}{*}{$\begin{array}{l}\text { Trait } \\
\text { Name of Breed }\end{array}$} & \multicolumn{4}{|l|}{ Fat Tailed Breeds } & \multicolumn{2}{|l|}{ Thin Tailed Breeds } \\
\hline & Akkaraman & Morkaraman & Dağlıç & İvesi & Kıvırcık & Karayaka \\
\hline Local Name of Breed & Akkaraman & Morkaraman & Dağlıç & İvesi & Kıvırcık & Karayaka \\
\hline Breed at risk & Not endangered & Not endangered & Nearly extinct & Not endangered & Not endangered & Not endangered \\
\hline Purpose of raising & Meat, milk & Meat & Meat, milk & Milk, meat & Meat & Meat, wool, milk \\
\hline Main region or country & Central Anatolia & East Anatolia & $\begin{array}{l}\text { Central-West } \\
\text { Anatolia }\end{array}$ & Southeast Anatolíc & $\begin{array}{l}\text { Thrace, Marmara } \\
\text { and North Aegean }\end{array}$ & $\begin{array}{l}\text { From Sinop to } \\
\text { Trabzon }\end{array}$ \\
\hline Color & $\begin{array}{l}\text { White body, } \\
\text { black spots on } \\
\text { muzzle, } \\
\text { ears and feet }\end{array}$ & $\begin{array}{l}\text { Light to dark } \\
\text { brown body }\end{array}$ & $\begin{array}{l}\text { White body, } \\
\text { black or brown } \\
\text { spots on muzzle, } \\
\text { ears and feet }\end{array}$ & $\begin{array}{l}\text { White body, } \\
\text { black or brown } \\
\text { spots on head, } \\
\text { neck and legs }\end{array}$ & $\begin{array}{l}\text { White body, } \\
\text { sometimes black or } \\
\text { pied }\end{array}$ & $\begin{array}{l}\text { White body, black } \\
\text { spots on head and } \\
\text { neck }\end{array}$ \\
\hline Polled or not & $\begin{array}{l}\text { Female not horn, } \\
\text { male has horn }\end{array}$ & $\begin{array}{l}\text { Female not horn, } \\
\text { male has horn }\end{array}$ & $\begin{array}{l}\text { Female not horn, } \\
\text { male has long, } \\
\text { spiral horn }\end{array}$ & $\begin{array}{l}\text { Female polled, } \\
\text { male horned }\end{array}$ & $\begin{array}{l}\text { Female not horn, } \\
\text { male has spiral horn }\end{array}$ & $\begin{array}{l}\text { Female not horn, male } \\
\text { has horn }\end{array}$ \\
\hline Height $(0,+\mathbf{c m})$ & - & 750,68 우 & $67 \lesssim, 61+$ & 6605 ㅇ & 690,64 ㅇ & 660,62 우 \\
\hline Body length $(0,+\mathbf{c m})$ & - & $72{ }^{3}, 67$ ㅇ & $65{ }^{\lambda}, 63$ 우 & $623,59+$ & 80,66 q & 7103 q 63 \\
\hline Birth weight $(0,+\mathbf{k g})$ & $4-4.9$ & $3.9 \jmath^{\lambda}, 3.5$ 우 & $3.5 \lesssim, 3.5$ 우 & $4.60^{2}, 4.4$ 우 & $4.0 \curvearrowright, 3.7$ ㅇ & $3.5 \overbrace{}^{\lambda}, 3.2$ 우 \\
\hline Adult weight $(\hat{\imath},+\mathbf{k g})$ & $50-60 \stackrel{\jmath}{2}, 35-40$ 우 & $50-90 \precsim, 40-60$ 우 & $53 \hat{\jmath}, 46$ 우 & $74 \jmath^{\lambda}, 50$ 우 & $60-70 \curvearrowright, 45-55$ 우 & 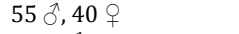 \\
\hline $\begin{array}{l}\text { Average daily gain for } \\
\text { fattening }(\mathrm{g})\end{array}$ & - & $192\left({ }^{1}\right)$ & $241\left({ }^{\Uparrow}\right)$ & $264\left(\bigcirc^{\lambda}\right)$ & $263\left({ }^{1}\right)$ & $220\left({ }^{\Uparrow}\right)$ \\
\hline Milk (kg) & $38-60$ & 60 & 57 & 172 & 83 & $40-50$ \\
\hline Lactation Length (days) & 125 & 126 & $75-105$ & 185 & 180 & $100-160$ \\
\hline Wool (Greasy) (kg) & $1.5-2.0$ & $1.5-2.0$ & 2.3 & 2.5 & 1.5 & $2-3.5$ \\
\hline Gestation age (month) & - & 18 & 18 & 18 & $16-18$ & 18 \\
\hline Lamb yield (\%) & 1.05 & 1.0 & 1.0 & 1.1 & 1.2 & 1.1 \\
\hline
\end{tabular}

(Sönmez 1975; Sönmez 1978; Ertuğrul et al 1993; TAGEM 2009)

1.1.3. Karayaka (Figure 3) lives in north Anatolia. It has coarse wool, long thin tail and small body size. Males are $55 \mathrm{~kg}$ and females are $40 \mathrm{~kg}$. Body coat colour is white with black eyes or black head and legs but occasionally black or brown. Males are usually thick, and spirally horned, females are usually polled (Mason 1996; Arat 2011).

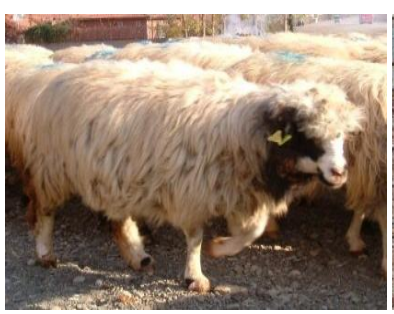

Figure 3. Karayaka Sheep

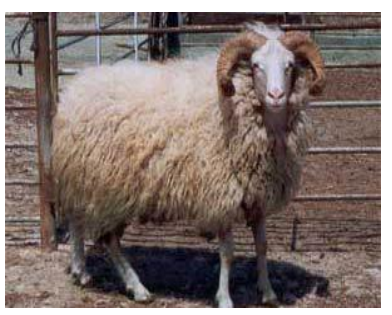

Figure 4. Kıvırclk Sheep
1.1.4. Kıvırcık (Figure 4) lives northwest Turkey. Kivirclk is meat and, milk type breed and has medium/coarse wool similar to Karnobat of Bulgaria and to Tsigai; part of Ruda (Balkans). They have white with white or spotted face but black and brown varieties. Kivirclk male is horned and female is usually polled. (Mason 1996). A total of 286 sheep (15 ram and 271 sheep) is kept under protection by government at Marmara Agricultural Research Institute (MARI) and 200 sheep are under protection by one farmer in Kirklareli (Ertuğrul et al. 2009). Because of different genetic structure Kivircik is possibly originated from European sheep Breeds (Koban 2004).

1.1.5. Morkaraman (Figure 5) is a dominant sheep breed of East Anatolia. It is a meat type and has light to dark brown body. Male is horned, and female is usually polled. Males are 50-90 kg, and females are 40-60 kg (TAGEM 2009).

1.1.6. Akkaraman (Figure 6) lives in central Anatolia. Is it a meat, and milk type breed. They have coarse wool. Coat colour is black on nose and face and occasionally around eyes. Male is usually polled, and female is polled (Mason 1996).

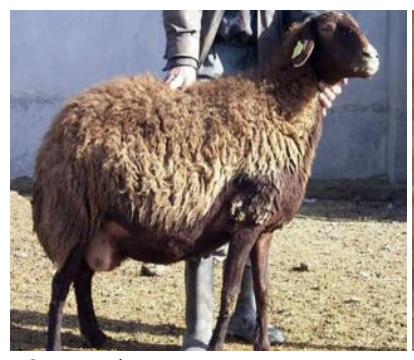

Figure 5. Morkaraman Sheep

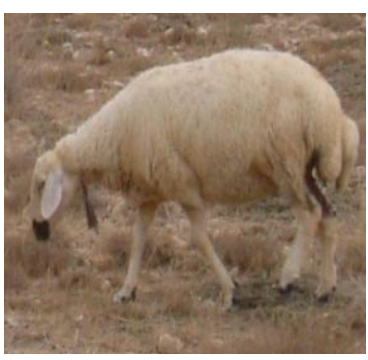

Figure 6. Akkaraman sheep

\subsection{Rare Breeds}

There are rare sheep breeds of Çandır, Çine Çaparı, Hemşin, Herik, İmroz (Gökçeada), Kangal Karaman, Karacadağ, Karagül, Karakaş, Karya, Norduz, Pırlak, Sakız, Güney Karaman, and Tuj in Turkey (Table 3). The breeds of İmroz (Gökçeada), Karya, Pırlak, and Sakız are thin tailed and rest is fat tailed.

1.2.1. Çandır (crossbred) is a crossbred of Dağlıç $x$ Akkaraman and lives in western Anatolia (Mason 1996), A synonym name is Kesber (Sönmez 1978).

1.2.2. Çine Çaparı (Figure 7) sheep are found in Aydın province. They are supposedly disease resistant. Females are $35 \mathrm{~kg}$ in adult weight. Coat colour is white, sometimes with light brown to black spots on feet and stomach (MARA/FAO 2000) They are also endangered breed. and nearly extinct. 120 sheep are under protection by two farmers in Aydın (Ertuğrul et al. 2009).

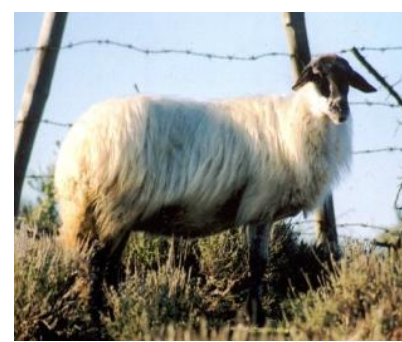

Figure 7. Çine Çaparı Sheep

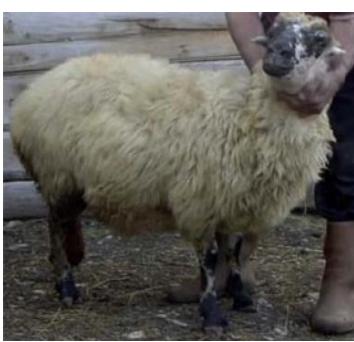

Figure 8. Hemşin Sheep 
Yılmaz et al./ BEU J SCI \& TECHNOL 2 (2012) 1-5

Table 3. Fat and thin tailed rare native sheep breeds of Turkey

\begin{tabular}{|c|c|c|c|c|c|c|c|c|c|c|c|c|}
\hline \multirow{2}{*}{$\begin{array}{l}\text { Trait } \\
\text { Name of Breed }\end{array}$} & \multicolumn{8}{|l|}{ Fat Tailed Breeds } & \multicolumn{4}{|c|}{ Thin Tailed Sheep Breeds } \\
\hline & Çine Çaparı & Karagül & Norduz & Tuj & $\begin{array}{l}\text { Güney } \\
\text { Karaman }\end{array}$ & Hemşin & Herik & $\begin{array}{l}\text { Kangal } \\
\text { Karaman }\end{array}$ & $\begin{array}{l}\text { Pirlak } \\
\end{array}$ & Karya & Sakız & İmroz \\
\hline Local Name of Breed & Çine Çaparı & Karagül & Norduz & Tuj & $\begin{array}{l}\text { Güney } \\
\text { Karaman }\end{array}$ & Hemşin & Herik & $\begin{array}{l}\text { Kangal } \\
\text { Akkaraman }\end{array}$ & Pirlak & Karya & Sakız & Gökçeada \\
\hline Breed at risk & Nearly extinct & Nearly extinct & Endangered & Nearly extinct & Endangered & Endangered & Endangered & Not endangered & Endangered & Endangered & Nearly extinct & Not endangered \\
\hline Purpose of raising & Meat, milk & Meat, milk, skin & Meat, milk & Meat, wool, milk & Meat, milk & Meat, wool & $\begin{array}{l}\text { Meat, milk, } \\
\text { wool }\end{array}$ & Meat, milk & Meat, milk & Milk, lamb & Milk, lamb & Milk, meat \\
\hline Main region or country & $\begin{array}{l}\text { Çine and } \\
\text { Bozdoğan } \\
\text { counties in Aydın } \\
\text { Province }\end{array}$ & $\begin{array}{l}\text { Province of } \\
\text { Tokat and } \\
\text { around }\end{array}$ & $\begin{array}{l}\text { Norduz Region in } \\
\text { Gürpınar County } \\
\text { of Van Province }\end{array}$ & $\begin{array}{l}\text { Çlldır County of } \\
\text { Kars, Ardahan, } \\
\text { Iğdır }\end{array}$ & $\begin{array}{l}\text { Provinces of } \\
\text { Antalya, } \\
\text { Mersin, } \\
\text { Hatay and } \\
\text { Gaziantep }\end{array}$ & $\begin{array}{l}\text { Artvin and Rize } \\
\text { Provinces }\end{array}$ & $\begin{array}{l}\text { Province of } \\
\text { Amasya }\end{array}$ & $\begin{array}{l}\text { Sivas and } \\
\text { adjacent } \\
\text { provinces in } \\
\text { Central Anatolia }\end{array}$ & $\begin{array}{l}\text { Kütahya, Afyon, } \\
\text { Ușak, Manisa, } \\
\text { Isparta, and } \\
\text { Burdur Provinces }\end{array}$ & $\begin{array}{l}\text { Provinces of } \\
\text { Aydın, İzmir, } \\
\text { Mani,sa, Uşak and } \\
\text { Denizli }\end{array}$ & $\begin{array}{l}\text { Çeşme, Urla and } \\
\text { Seferihisar in } \\
\text { İzmir Province }\end{array}$ & $\begin{array}{l}\text { Island of } \\
\text { Gökçeada, } \\
\text { Canakkale } \\
\text { Province }\end{array}$ \\
\hline Color & $\begin{array}{l}\text { Beige or light grey } \\
\text { body; } \\
\text { dark spots head, } \\
\text { ears, legs and } \\
\text { abdomen }\end{array}$ & $\begin{array}{l}\text { Commonly } \\
\text { black, rarely } \\
\text { brown, grey or } \\
\text { white body }\end{array}$ & $\begin{array}{l}\text { Commonly white, } \\
\text { rarely gray, grey, } \\
\text { brown, or white } \\
\text { body }\end{array}$ & $\begin{array}{l}\text { Shiny white body; } \\
\text { dark spots on } \\
\text { head, and, legs }\end{array}$ & $\begin{array}{l}\text { White, grey, } \\
\text { brown, red, } \\
\text { black and } \\
\text { pied body }\end{array}$ & $\begin{array}{l}\text { From brown to } \\
\text { black, sometimes } \\
\text { light gray }\end{array}$ & $\begin{array}{l}\text { White body, } \\
\text { sometimes } \\
\text { black or } \\
\text { brown, dark } \\
\text { spots on } \\
\text { head, legs }\end{array}$ & $\begin{array}{l}\text { White body, } \\
\text { black spots } \\
\text { around mouth } \\
\text { and eyes }\end{array}$ & $\begin{array}{l}\text { White body with } \\
\text { black spots around } \\
\text { mouth, eyes, on } \\
\text { ears }\end{array}$ & $\begin{array}{l}\text { White body with } \\
\text { lblack spots around } \\
\text { mouth, eyes, on } \\
\text { ears }\end{array}$ & $\begin{array}{l}\text { White body with } \\
\text { lblack spots around } \\
\text { mouth, eyes, on } \\
\text { ears and legs }\end{array}$ & $\begin{array}{l}\text { White body with } \\
\text { black spots around } \\
\text { mouth, eyes, on } \\
\text { ears and legs }\end{array}$ \\
\hline Polled or not & $\begin{array}{l}\text { Female mostly } \\
\text { not horn, male } \\
\text { has big spiral } \\
\text { horn }\end{array}$ & $\begin{array}{l}13 \% \text { of female } \\
\text { horn, male has } \\
\text { horn }\end{array}$ & $\begin{array}{l}\text { About } 50 \% \text { of } \\
\text { female horn, male } \\
\text { has horn }\end{array}$ & $\begin{array}{l}\text { Female mostly } \\
\text { polled, male has } \\
\text { spiral horn }\end{array}$ & $\begin{array}{l}\text { Female } \\
\text { rarely has } \\
\text { horn, male } \\
\text { has horn }\end{array}$ & $\begin{array}{l}\text { Female sometimes } \\
\text { horn, male has big, } \\
\text { spiral horn }\end{array}$ & $\begin{array}{l}\text { Female } \\
\text { polled, male } \\
\text { horned }\end{array}$ & $\begin{array}{l}\text { Female not } \\
\text { horn, } 10 \% \text { of } \\
\text { male has horn }\end{array}$ & $\begin{array}{l}\text { Female not horn, } \\
\text { male has spiral } \\
\text { horn }\end{array}$ & $\begin{array}{l}\text { Female not horn, } \\
\text { male has spiral } \\
\text { horn }\end{array}$ & $\begin{array}{l}\text { Female not horn, } \\
\text { male has horn }\end{array}$ & $\begin{array}{l}\text { Female polled, } \\
\text { male has spiral } \\
\text { horn }\end{array}$ \\
\hline $\begin{array}{l}\text { Height }(\hat{\lambda}, q \mathbf{c m}) \\
\text { Body length }\left(\partial^{\lambda}, q \mathbf{c m}\right)\end{array}$ & 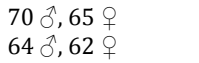 & $\begin{array}{l}65 \partial^{\lambda}, 58 \text { o } \\
66 \hat{o}^{\lambda}, 58 \text { q }\end{array}$ & $\begin{array}{l}71 \stackrel{+}{9} \\
68+9\end{array}$ & $\begin{array}{l}61 \text { 운 } \\
71+9\end{array}$ & 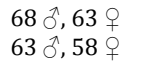 & $\begin{array}{l}79 \hat{d}, 73 \text { o } \\
72 \hat{\partial}, 68 \text { q }\end{array}$ & $\begin{array}{l}65 \AA, 61 \text { o } \\
67 \hat{\jmath}, 62 \text { + }\end{array}$ & $\begin{array}{l}- \\
-\end{array}$ & $\begin{array}{l}63 \text { 品 } \\
60+9\end{array}$ & $\begin{array}{l}67 \stackrel{9}{9} \\
64 \stackrel{+}{+}\end{array}$ & $\begin{array}{l}75 \hat{d}, 73 \text { q } \\
75 \hat{\jmath}, 72 \text { q }\end{array}$ & $\begin{array}{l}61 \text { 운 } \\
63 \text { + }\end{array}$ \\
\hline $\begin{array}{l}\text { Birth weight }(\hat{n},+ \text { kg) } \\
\text { Adult weight }(\hat{\infty},+\mathbf{k g})\end{array}$ & 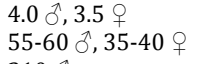 & $\begin{array}{l}3.3 \overbrace{}^{\lambda}, 3.19 \\
58{ }^{\lambda}, 38 q\end{array}$ & 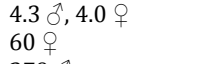 & 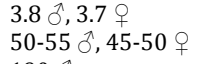 & $\begin{array}{l}4.2 \AA, 3.6 \text { q } \\
52 \AA, 37 q\end{array}$ & 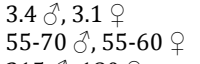 & $\begin{array}{l}3.5 \stackrel{\lambda}{\lambda}, 3.3 \text { q } \\
60 \stackrel{\curvearrowright}{\curvearrowright}, 47 q\end{array}$ & - & $\begin{array}{l}4.0 \AA, 3.5 \text { ㅇ } \\
45-50 \text { q }\end{array}$ & $\begin{array}{l}4.5 \overbrace{}^{\lambda}, 3.5 q \\
55 \overbrace{}^{\lambda}, 45 q\end{array}$ & $\begin{array}{l}3.2 \overbrace{}^{\lambda}, 3.0 \text { q } \\
70 \overbrace{}^{2}, 50 \text { q }\end{array}$ & $\begin{array}{l}3.8 \overbrace{}^{2}, 3.7 \text { q } \\
55 \overbrace{}^{\lambda}, 48+9\end{array}$ \\
\hline $\begin{array}{l}\text { Average daily gain for } \\
\text { fattening (g) }\end{array}$ & $210 \delta^{\lambda}$ & - & $279 \overbrace{}^{\lambda}$ & $190 \delta^{\lambda}$ & $275 \delta^{\pi}$ & $215 \delta^{\lambda}, 180$ 우 & - & - & 150 oे $^{\lambda}$ & $182 \sigma^{\lambda}$ & $242 \partial^{\lambda}$ & $191 \partial^{\lambda}$ \\
\hline Milk (kg) & 50 & - & 137 & 45 & $25-30$ & 110 & - & - & $75-80$ & 100 & $180-200$ & 121 \\
\hline Lactation Length (days) & $145-150$ & - & 182 & 124 & - & $135-170$ & - & - & 120 & 170 & 190 & 204 \\
\hline Wool (Greasy) (kg) & 1.2 & $1.8-3.0$ & - & - & 2.7 & 1.7 & $1.8-3.5$ & - & $2-2.5$ & 1.0 & 2 & 2.2 \\
\hline Gestation age (month) & & $11-18$ & - & - & 18 & 18 & 18 & - & 18 & $10-14$ & $8-9$ & 16 \\
\hline Lamb yield (\%) & 1.1 & 1.0 & 1.1 & 1.2 & 1.0 & 1.1 & 1.1 & - & $1.2-1.5$ & 1.6 & 2.0 & 1.2 \\
\hline
\end{tabular}

(Sönmez 1975; Sönmez 1978; Ertuğrul et al 1993; TAGEM 2009)

1.2.3. Hemşin (Figure 8) is a variety of Morkaraman of northeast Turkey. It is a coarse wool, and meat type breed. Coat colour is brown, black or white. Male is horned, and female is usually polled. Tail is long with fat at base (Mason 1996). Hemşin is endangered and 200 sheep are under protection by one farmer in Ardanuç, Artvin (Ertuğrul et al. 2009).

1.2.4. Herik (Figure 9) of north Anatolia coarse wool, meat and milk type. Similar to Dağlıc usually white with dark spots on head; male horned, female usually polled; short fat tail (Mason 1996), endangered and 200 sheep are under protection by three farmers in Amasya (Ertuğrul et al. 2009).

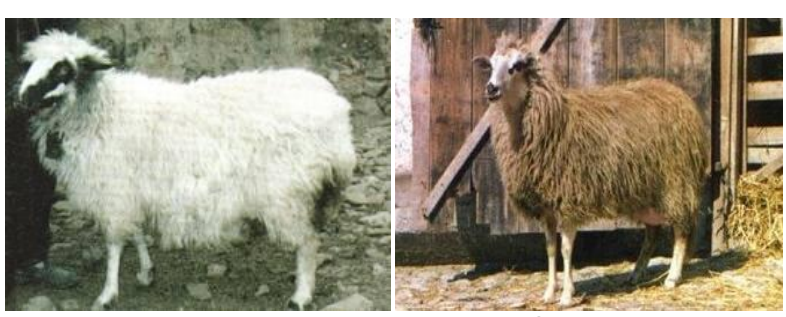

Figure 9. Herik Sheep
Figure 10. İmroz Sheep
1.2.5. İmroz (Figure 10) is milk, meat and coarse wool type breed. Male is horned, and female is polled or scars. A synonym name is Gökçeada (Mason 1996). A total of 94 sheep (18 ram and 76 sheep) is under protection by government and 200 sheep are under protection by two farmers in Gökçeada, Çanakkale (Ertuğrul et al. 2009).

1.2.6. Kangal Karaman lives in Sivas and Malatya provinces and is a local variety of Akkaraman (Mason 1996). It has white body, black spots on head. $5 \%$ of males have horn, and female is polled (TAGEM 2009). 
1.2.7. Karacadağ of Diyarbakır is a local variety of Morkaraman near province of Diyarbakır (Mason 1996).

1.2.8. Karagül (Figure 11) is endangered, and 200 sheep are under protection by two farmers in Tokat (Ertuğrul et al. 2009). It is a meat, and milk type breed. Coat colour of Karagül is commonly black, rarely brown, grey or white. $13 \%$ of female and male has horn (TAGEM 2009). 200 sheep are under protection by two farmers in Tokat (Ertuğrul et al. 2009)

1.2.9. Karakaş is endangered sheep breed (Ertuğrul et al. 2009) and lives in Southeast Anatolia. It is a variety of Akkaraman. It has white body, and black spots on head (Sönmez 1978).

1.2.10. Karya lives in provinces of Aydın, İzmir, Manisa, Uşak and Denizli. It has coarse wool, small body size and is meat and milk type. Karya has usually white body with black spots around mouth, eyes, on ears. Male is usually thick, strong and spirally horned, female is usually polled. It has long thin tail (TAGEM 2009), and is endangered (Ertuğrul et al. 2009).

1.2.11. Norduz is a local breed of Norduz Region in Gürpınar County of Van Province of east Turkey. Coat colour is commonly white, rarely gray, grey, brown, or white. Norduz is a meat and milk type breed. Male is horned, and female is $50 \%$ polled. It is a fat tail breed. Norduz is endangered and 200 sheep are under protection by eleven farmers in province of Van (TAGEM 2009; Ertuğrul et al. 2009).

1.2.12. Pırlak lives in Afyon, Burdur, Isparta, Kütahya, Manisa, and Ușak. It has coarse wool, and mid-sized body. Coat colour is usually white with black spots around mouth, eyes, on ears. Male is usually strong and spirally horned, female is usually polled. Tail is long with fat at base (TAGEM 2009), and endangered (Ertuğrul et al. 2009).

1.2.13. Sakız (Figure 12) lives in İzmir. Coat colour is white with black spots around mouth and eyes and on ears and legs. Male is horned, and female is usually polled. Tail is long with fat at base (Mason 1996). It is nearly extinct, and a total of 130 sheep (35 ram and 95 sheep) is under protection by government and 113 sheep are under protection by four farmers in Çeşme, İzmir (Ertuğrul et al. 2009).

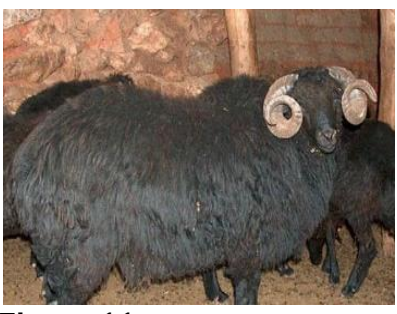

Figure 11. Karagül Sheep

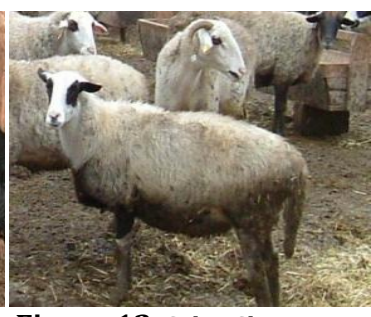

Figure 12. Sakız Sheep
1.2.14. Güney Karaman (Figure 13) is black variety of Ak Karaman from Antalya, Mersin, Hatay and Gaziantep Provinces of South Anatolia (Mason 1996). It is a meat and milk type breed. Coat colour is white, grey, brown, red, black and pied. Female rarely has horn, male has horn. Male is about $52 \mathrm{~kg}$, and female is $37 \mathrm{~kg}$ (TAGEM 2009). It is endangered, and a total of 46 sheep ( 24 ram and 22 sheep) is under protection by government at Bahri Dağdaş International Agricultural Research Institute (Ertuğrul et al. 2009).

1.2.15. Tuj (Tushin) (Figure 14) lives in in Kars, Ardahan and Iğdır Provinces. It is a meat, coarse wool and milk type breed. Coat colour is sometimes dark marks around eyes and on feet. Male is about $50-55 \mathrm{~kg}$, and female is $45-50 \mathrm{~kg}$. Male is horned, and female is polled. Tuj has short fat tail or fat rump. This breed is originally from Georgia (Mason 1996; TAGEM 2009) and nearly extinct (Ertuğrul et al. 2009).

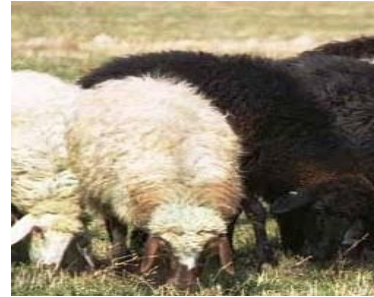

Figure 13. Güney Karaman

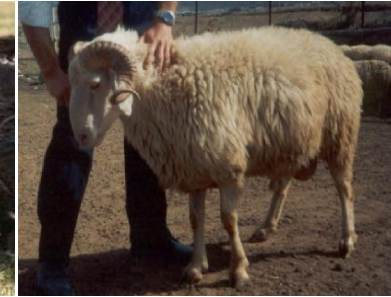

Figure 14. Tuj Sheep

\section{Conclusion}

Sheep husbandry has lots of advantages unlike other farm animals. Sheep can be raised in different environmental conditions. They have many product and by product such as meat, milk, wool, skin, intestine and dung. They can consume roughage efficiently. Their sheepfold can be built lesser money than cattle. Because of many advantages sheep population decreased to half in 30 years.

Some breeds have been extinct and some of them nearly extinct and endangered. Therefore in 1995 The Preservation of Farm Animal Genetic Resources (FAnGR) Project started to preserve cattle breeds which were endangered. In 1996 breeds of sheep were included into the project. Hence, 14 sheep breeds were covered by this project (Table 4).

Table 4. Places and breeds/lines under preservation

\begin{tabular}{|c|c|}
\hline Breed/line & Place \\
\hline $\begin{array}{l}\text { Karayaka, Herik, Çine } \\
\text { Çaparı, Karagül, İvesi, } \\
\text { Dağlıç, Cine, }\end{array}$ & $\begin{array}{l}\text { Lalahan Livestock Research Institute } \\
\text { (LLRI), Ankara }\end{array}$ \\
\hline $\begin{array}{l}\text { Sakız, Kıvırcık, İmroz } \\
\text { (Chios) }\end{array}$ & $\begin{array}{l}\text { Marmara Livestock Research Institute } \\
\text { (MLRI), Balıkesir }\end{array}$ \\
\hline Akkaraman & $\begin{array}{l}\text { Bahri Dağdaş International } \\
\text { Agricultural Research Institute } \\
\text { (BDIARI), Konya }\end{array}$ \\
\hline $\begin{array}{l}\text { Morkaraman, Hemşin, } \\
\text { Norduz }\end{array}$ & $\begin{array}{l}\text { Bahri Dağdaş International } \\
\text { Agricultural Research Institute } \\
\text { (BDIARI), Konya }\end{array}$ \\
\hline
\end{tabular}

(TAGEM 2009)

After five years, DNA, cell and embryos were gathered for 13 sheep breeds and they are placed into two research institiute (Table 5). However none of the breeding programmes have been succeded completely. One of the most important reasons was that $90 \%$ of Turkish sheep populations have a fat tail. The fat tail always needs human manipulation to mate native sheep to foreign thin tail sheep. Native sheep breed rams can lift the tail to mate female sheep, but foreign thin tail ram never can lift the tail to mate females. 
Table 5. Current DNA and Cell Bank Contents of sheep in May 2011

\begin{tabular}{|c|c|c|c|c|c|c|}
\hline \multirow{2}{*}{ Breed } & \multicolumn{2}{|c|}{ GEBI, Gebze, Kocaeli } & \multicolumn{2}{|c|}{ LLCRI, Lalahan, Ankara } & \multirow[b]{2}{*}{ DNA } & \multirow[b]{2}{*}{ Cell } \\
\hline & DNA & Cell & Embrio & Sperm & & \\
\hline Karayaka & $49 \mathrm{indv}$. & 64 indv., 292 vial & 136 & 25 indv., 663 straws & $49 \mathrm{indv}$. & - \\
\hline Herik & 49 indv. & 48 indv., 480 vial & 50 & 18 indv., 603 straws & 49 indv. & 47 indv., 470 vial \\
\hline Gökçeada & 50 indv. & 49 indv., 490 vial & 102 & 23 indv., 730 straws & 50 indv. & 49 indv., 490 via \\
\hline Karagül & $50 \mathrm{indv}$. & 48 indv., 283 vial & 60 & 13 indv., 465 straws & $50 \mathrm{indv}$. & \\
\hline Morkaraman & 50 indv. & 44 indv., 184 vial & 173 & 13 indv., 556 straws & 50 indv. & \\
\hline Akkaraman & $50 \mathrm{indv}$. & $49 \mathrm{indv} ., 490$ vial & 65 & 23 indv., 704 straws & $50 \mathrm{indv}$. & $44 \mathrm{indv.,} 440 \mathrm{via}$ \\
\hline Sakız & $49 \mathrm{indv}$. & $47 \mathrm{indv} ., 470 \mathrm{vial}$ & 22 & 7 indv., 298 straws & $49 \mathrm{indv}$. & $47 \mathrm{indv.,} 470 \mathrm{via}$ \\
\hline Kivircik & $45 \mathrm{indv}$. & 43 indv., 195 vial & 185 & 21 indv., 656 straws & $45 \mathrm{indv}$. & - \\
\hline İvesi & $51 \mathrm{indv}$. & $51 \mathrm{indv} ., 183$ vial & 50 & 23 indv., 681 straws & $51 \mathrm{indv}$. & - \\
\hline Dağlıç & $50 \mathrm{indv}$. & 50 indv., 192 vial & 8 & 19 indv., 635 straws & $50 \mathrm{indv}$. & - \\
\hline Çine Çaparı & $39 \mathrm{indv}$. & $39 \mathrm{indv} ., 390$ vial & 38 & $16 \mathrm{indv}$., 530 straws & 39 indv. & $34 \mathrm{indv.,} 340 \mathrm{via}$ \\
\hline Hemşin & $48 \mathrm{indv}$. & 48 indv., 284 vial & 64 & $18 \mathrm{indv}$., 550 straws & $48 \mathrm{indv}$. & \\
\hline Norduz & 54 indv. & 49 indv., 490 vial & 36 & 23 indv., 807 straws & 54 indv. & $49 \mathrm{indv} ., 490 \mathrm{via}$ \\
\hline
\end{tabular}

(TÜRKHAYGEN-I 2011), GEBI: Genetic Engineering and Biotechnical Institute, LLRI: Lalahan Livestock Research Institute.

Always government or university breeding programmes are carried out using some expert staff or technicians to mate foreign thin tail rams to native fat tail females. Under rural conditions villager farmers never achieve human manipulation mating; hence this kind of programme cannot be applied at rural conditions. At the east and southeast of Anatolia huge amount of grasslands cannot be used by sheep flocks because of terror problem. Rural site people migrate from villages to metropolis cities due to insufficient life conditions so that they give up sheep breeding.

Table 6. Extinction and risk situations of Turkish native sheep breeds.

\begin{tabular}{|c|c|c|c|c|}
\hline Breed and Type & $\begin{array}{c}\text { Not } \\
\text { endangered }\end{array}$ & Endangered & $\begin{array}{l}\text { Nearly } \\
\text { extinct }\end{array}$ & Extinct \\
\hline $\begin{array}{l}\text { Ak, Mor and } \\
\text { Kangal Karaman, } \\
\text { Kıvircık, İvesi, } \\
\text { Karayaka,İmroz }\end{array}$ & $x$ & & & \\
\hline $\begin{array}{l}\text { Güney Karaman, } \\
\text { Herik, Hemşin, } \\
\text { Karya, Karakaş, } \\
\text { Norduz }\end{array}$ & & $\mathrm{x}$ & & \\
\hline $\begin{array}{l}\text { Dağlıç, Tuj, Sakız, } \\
\text { Cine, Capari }\end{array}$ & & & $x$ & \\
\hline $\begin{array}{l}\text { Odemis, Halkali, } \\
\text { Karakachan }\end{array}$ & & & & $x$ \\
\hline
\end{tabular}

(Ertuğrul et al. 2009; Ertuğrul et al. 2010)

Crop fields become smaller year by year because of heritage for every generation and sheep breeders cannot produce enough roughage and food for sheep. Because of such reasons, amount of sheep population decreases year by year and sheep breeds disappears rapidly (Table 6). Preservation policies should go on and present breeds should be survived for future generations.

\section{References}

Arat S (2011). In vitro conservation and preliminary molecular identification of some Turkish domestic animal genetic resources (TÜRKHAYGEN-I). Genetic Engineering and Biotechnology Institute, Gebze, Kocaeli, Turkey.

Ertuğrul M, Akman N, Așkın Y, Cengiz F, Fıratli C, Turkoglu M, Yener SM (1993). Hayvan yetiștirme (Yetiștiricilik). Baran Ofset, Ankara, $288 \mathrm{p}$.

Ertuğrul M, Dellal G, Soysal IM, Elmaci C, Akin 0, Arat S, Baritci I, Pehlivan E, Yılmaz, O (2009). Türkiye yerli koyun irklarının korunması. Uludağ Univ Ziraat Fak Derg 23, 97-119.
Ertuğrul M, Dellal G, Elmaci C, Akin AO, Pehlivan E, Soysal MI, Arat (2010). Ciftlik hayvanları genetik kaynaklarının kullanılması ve sürdürülebilir kullanımı. Türk Ziraat Mühendisliği VII. Teknik Kongresi, 11-15 Ocak 2010, 179-198 pp.

MARA/FAO (2001). Agriculture in Turkey, Güzeliş Ltd. Ankara, 231 p. (ISBN 975-8153-00-5).

Kaymakçı M (2008). Türkiye koyunculuğunda melezleme çalışmaları. Hayvansal Üretim 49, 43-51.

Koban E (2004). Genetic diversity of native and crossbreed sheep breeds in Anatolia. The Graduate School of Natural and Applied Sciences, PhD Thesis, Middle East Technical University.

Mason IL (1996). A world dictionary of livestock breeds, types and varieties (4th Edition). CAB International: Wallingford, UK, $496 \mathrm{pp}$.

Sönmez R (1975). Özel zootekni. Ege Üniversitesi Ziraat Fakültesi Yayınları: 141, İzmir, 228 pp.

Sönmez R (1978). Koyunculuk ve yapağı. Ege Üniversitesi Ziraat Fakültesi Yayınları: 108, İzmir, 388 pp.

Sönmez R (2009). Türkiye koyun ıslahı çalışmaları. Uludag Üniv Ziraat Fak Derg 23, 43-65.

TAGEM (2009). Türkiye çiftlik hayvanları genetik kaynakları kataloğu. Tarım ve Köyişleri Bakanlığı, Tarımsal Araștırmalar Genel Müdürlügü, Ankara, 96 p.

TÜRKHAYGEN-I (2011). TÜRKHAYGEN-I Projesi (www.türkhaygen.gov.tr, accessed on 07.10.2011).

Türkiye İstatistik Kurumu (2011). Hayvancıllk istatistikleri (http://www.turkstat.gov.tr, accessed on 23.12.2010)

Yılmaz O (1995). Some repeatability and heritability characters on Scottish Blackface sheep. Faculty of Agriculture, MSc Thesis, Aberdeen University, UK. 